УДК 681.3.06:519.6

\title{
GENERALIZED ACCURACY AS A MEASURE OF QUALITY SYSTEMS OF EXPERIMENTAL DATA PROCESSING WHEN ROUGHNESS ANALYSIS IN THE AIRCRAFT INDUSTRY
}

Miroshnichenko I.V.

National Technical University of Ukraine "Igor Sikorsky Kyiv Polytechnic Institute" (Ukraine)

Information technology, which uses the concept of generalized precision systems of experimental data processing, which is characterized by a given set of indicators of measurement theory and reliability, with the definition of savedocument (zavadoski) and electromagnetic compatibility, can be used when designing systems for measuring the parameters of signals and noise of various kinds. Study of characteristics of problem areas of the aircraft (Problem area - PRAR) is not possible without knowledge of the properties of the measuring signals and noise at the input of the systems of experimental data processing (CONN), often described by probabilistic characteristics.

Most research methods PRAR provide only probabilistic characteristics of signals, mathematical models which are stochastic processes-PRAR that describe interference during signal transfer.

When working with deterministic signals, such as direct measurements of the roughness of surfaces and some others, the received signals are the mixture of dimensional deterministic signal and noise obtained from the action of the environment on the signal (signal attenuation).

The concept of generalized precision could serve as a basis for development of methodical, software and technical support for statistical multiband and multifunctional systems of experimental data processing in the study of the roughness of the products of aviation technology with a given tolerance, and metrological certification and verification software and verification capabilities of statistical measurements can be carried out according to specified rules.

Key words: mathematical model, information technology, generalized precision, the system for processing experimental data.

Statement of the problem. As a rule, the characteristics of multidimensional funkcj distribution point functions, the characteristic 
function is performed by system characteristics Jomon functions. The theory of measurement characteristics of the object includes a physical process. Unlike her normal form submission process is the serial dependence of time or a set of variables in Adnan the same time casu Mismatch between the real processes in the Prar with mathematical models that characterize the accuracy of the mathematical model and the real object in a specific Prar. The study of the characteristics of accuracy of the mathematical model will allow to assess the overall accuracy of the study.

Analysis of recent research. The study of mathematical development in the aviation industry [2] with measurement blunders in aviation can serve as the basis for development of methodical, software and technical support to statistical systems of experimental data processing. If erroneous determination takes into account all sources of error that are considered in the theories of instrumental precision, reliability, noise immunity, electromagnetic compatibility, the accuracy of such system can be called generalized accuracy of the system [4], which is characterized by a set of indicators, or precision in a broad sense. This approach enables the processing of measurement results and, in some cases, their interpretation, because of indicator of the quality UNIT needs to be generalized precision.

A General classification of statistical studies based on the use of four parameters such as the class of the random process under consideration, the statistical characteristics, the type used by the operator of the Assembly, the average dimension of the evaluation and the type of organization and measurement of the experiment [8].

In [3] proposed a classifier - statistical problems of measurement that allows executing a number of problems of statistical measurement in the external phase of the study, which is a scientific basis for creating units of valuation accuracy. Using the application of analog-digital statistics analog-digital devices, allows to increase the speed of processing of experimental data $[2,3,4]$.

In practice, the most important is always a sign of class process $[1,3$, 8], the explanation, which is based on statistical radio engineering, hydro acoustics, optics, and processing the results of parameters of roughness. In General, the process class can often come only after lengthy and costly experiments or in the treatment of "Indirect". This formulation reflects the General trend in the development of methods for analysis of random processes and principles of work of the statistical unit in the study of performance evaluation for simulation of physical phenomena in a particular area [1].

The article goals. To investigate and establish criteria for the existence of the approximation accuracy for statistical studies of the experimental data based on the calculation of the total error. 
The main part. Let a random process with a specified density of the probability distribution allows for the standardization of the whole process. On the basis of standard terms [3], considering that the evaluation of the statistical characteristics - some function from its average value, it can be defined as primary.

The initial moments of the first stage is then processed using the integral forms. If these integrals exist and are defined as the average, then result is assigned the sign "-".

Any stage of the calculation is the description of a defined process. Not all of these processes can be described by a function. That is, the distribution density of probability exists only on a finite interval. For example, in the process with a uniform distribution, all moments exist.

Suppose process can consider the infinite series or the error of their subtraction, if you have a random process. Such a process is represented with the function Fourier. This is the characteristic function of the process. Integral to the process is divergent i.e. the main value is not finite.

Quality indicator, which has the ability any product is called determining the quality indicator Q. so ID take the weighted Q, bounding the allowable error value or a valid error whole unit, or only one measuring channel. For other systems, for example, the transmission of information, the quality $\mathrm{Q}$ can be adopted erroneous symbol, the transmission reliability and so on. But in any case, the system of measurement of informative parameters of signals depends on the noise of different origin. From the metrological point of view, the evolution of information technology is determined by:

the principle of classification errors;

- characteristics of the software errors;

- the increase of the number and complexity of measurement;

- improving the technical basis.

The diverse nature of the individual sources of error which leads to the need to describe their action is different, sometimes incompatible formal indicators. However, this usually does not take into account the effect of the interaction of some sources of errors (or their groups). Neglecting them in some cases is unacceptable, especially in multi-channel Soed. Experimental determination of this dependence can be long and costly, especially in cases of development of unique systems in aircraft construction $[1,2]$.

The results of experiments are considered as samples and processes that control and necessarily allow the existence of a probability distribution in the functional space, such as time. Measuring the probability characteristics of random processes assigns a significant part of the applications, however, it is possible to interpret the results for another, for example, random field measurements. 
Conclusions. Information technology, using the concept of generalized accuracy Soed, which is characterized by a set of indicators of measurement theory and reliability to determine noise immunity (noise immunity) and electromagnetic compatibility, can be used in designing systems for measuring signal parameters and interventions of different types and origins. Using the concept of generalized accuracy, software verification, metrological certification and verification of statistical measurements can be performed according to generally defined rules.

\section{Literature}

1. Detling V. S., Zinchenko V. P., Miroshnichenko I. V. Data-measuring system of quality assurance of surface roughness. Bulletin of Cherkasy State technological University, Special issue, 2006, P. 135-137.

2. Zinchenko V. P., Borisov V. V., Miroshnichenko I. V. Algorithm for optimal design of aircraft. Vestnik of East-Ukrainian national University. Vladimir dal. Scientific journal № 13 (167). 2011. P. 70-74.

3. Marchuk N. A. Miroshnichenko I. V. Classification of statistical measurement tasks. proceedings of international scientific-technical conference "automation: Problems, ideas, solutions", Sevastopol, 2012. P. 170-171.

4. Marchuk N. A., Miroshnichenko I. V. Generalized systems accuracy of experimental data processing. Scientific Bulletin of East Ukrainian national University. Vladimir Dahl, Lugansk, 2012. № 8 (179), CH 2. With 121-130.

5. Miroshnichenko V. S., K. L. Serpilin Error from the quantization of the measurements of Central moments of random processes. proc. Dokl. resp. nauchno-tekhn. Conf. "The use of computers and mathematical methods in scientific researches", Ternopil, 1986. P. 22.

6. Ponomarenko V. K., Miroshnichenko, V. S., Choice of parameters of measure the numerical characteristics of random processes, Izv. The UNIVERSITY of the USSR, div. Electronics, XVI, 1971. P. 111.

7. Ponomarenko V. K., Miroshnichenko V. S. Improving the accuracy of the calculation of high order moments of random processes with a limited range of values. Proceedings of IV all-Union School-seminar on statistical hydroacoustics Novosibirsk, 1973. P. 55-59.

8. Zvetkov E. S. Fundamentals of the theory of statistical measurements. 2nd ed. Rev. and additional. L.: Energoatomizdat, 1986. 286 p. 


\title{
ОБОБЩЕННАЯ ТОЧНОСТЬ КАК ПОКАЗАТЕЛЬ КАЧЕСТВА СИСТЕМ ОБРАБОТКИ ЭКСПЕРИМЕНТАЛЬНЫХ ДАННЫХ ПРИ АНАЛИЗЕ ШЕРОХОВАТОСТИ В АВИАСТРОЕНИИ
}

\author{
Мирошниченко I.B.
}

Информационные технологии, использующче концепциию обобщенной точности систем обработки экспериментальных данных, которая характеризуется учетом совокупности показателей теории измерений и надежности с определением помехозащчищенности (помехоустойчивости) и электромагнитной совместимости, могут быть использовань при проектировании систем для измерения параметров сигналов и помех различных видов. Исследование характеристик проблемных областей авиации (Problem area - PRAR) невозможны без знания свойств измерительных сигналов и помех на входе систем обработки экспериментальных данных (СОЕД), чаще всего описываемых вероятностными характеристиками.

Большинство методов исследования PRAR предусматривают работу только с вероятностныли характеристиками сигналов, математическими моделями которых являются случайные процессы, описывающие PRAR и помехи при передаче сигналов.

При работе с детерминированными сигналами, например, при прямых измерениях иероховатости поверхностей и некоторых других приложений, полученные сигналы являются смесью измерительного детерминированного сигнала и помех, как от воздействия среды на сигнал (затухание сигнала), так и от влияния сигнала на среду.

Конщепция обобщенной точности может служить основой для разработки методического, программного и технического обеспечения статистических многоканальных и многофункииональных систем обработки экспериментальных данных при измерении шероховатости изделий авиационной техники с заданной погрешностью, а метрологическая аттестация, верификация программного обеспечения и поверка средств статистических измерений могут проводиться по определенным правилам

Ключевые слова: математическая модель, информационнье технологии, обобщенная точность, система обработки экспериментальных данных 


\title{
УЗАГАЛЬНЕНА ТОЧНІСТЬ ЯК ПОКАЗНИК ЯКОСТІ СИСТЕМ ОБРОБКИ ЕКСПЕРИМЕНТАЛЬНИХ ДАНИХ ПРИ АНАЛІЗІ ШОРСТКОСТІ В АВІАБУДУВАННІ
}

\author{
Мірошниченко I.B.
}

Інформаційні технології, що використовують конщепцію узагальненої точності систем обробки експериментальних даних, які характеризується обліком сукупності показників теорії вимірів $i$ надійності, з визначенням заводозахищеності (заводостійкій) $i$ електромагнітної сумісності, можуть бути використані при проектуванні систем для виміру параметрів сигналів $i$ перешкод різних видів. Дослідження характеристик проблемних областей aвiauiï (Problem area - PRAR) неможливі без знання властивостей вимірювальних сигналів $i$ перешкод на вході систем обробки експериментальних даних (СОЕД), найчастіме описуваних імовірнісними характеристиками.

Більшість методів дослідження PRAR передбачають роботу тільки з ймовірнісними характеристиками сигналів, математичними моделями яких с випадкові проиеси-PRAR, що описують, перешкоди при передачі сигналу.

При роботі з детермінованими сигналами, таких як прямі виміри шорсткості поверхонь та деяких інших, отримані сигнали $\epsilon$ сумішшю вимірного детермінованого сигналу та перешкод отриманих від дії середовища на сигнал (затухання сигналу).

Кониепиією узагальненої точності може слугувати основою для розробки методичного, програмного та технічного забезпечення статистичних багатоканальних та багатофункціональних систем обробки експериментальних даних при дослідженні шорсткості виробів авіаційної техніки з заданою похибкою, а метрологічна атестація та верифікація програмного забезпечення та перевірка можливостей статистичних вимірів можуть проводитись по заданим правилам.

Ключові слова: математична модель, інформачійні технології, узагальнена точність, система обробки експериментальних даних. 